\title{
EFFECTIVE TEACHING METHODOLOGY FOR TEACHING ENGLISH AS A SECOND LANGUAGE AT TERTIARY LEVEL
}

\author{
Areeba Arif \\ Co-operative Lecturer, \\ Department of English, Jinnah University for Women, \\ Sindh, Pakistan \\ Email: areeba.arif@juw.edu.pk

\section{Syeda Sarah Junaid} \\ Lecturer, \\ Department of English, Jinnah University for Women, \\ Sindh, Pakistan \\ Email: sarah.junaid@juw.edu.pk

\section{Salma Niazi} \\ Lecturer, \\ Department of English, Jinnah University for Women, \\ Sindh, Pakistan \\ Email: salma.niazi@juw.edu.pk
}

\begin{abstract}
English language is a global language and it is essential for a second language learner to be proficient in it. It is the second language and has become the language of television, newspaper, law, mass media, radio, social circles, documentation, technology and economy in our country. So, it should be taught in a way that it will fulfill all the requirements properly. The day by day increasing demand of this language has also increased the demand of competent students. But most of the students cannot use English properly even after graduating. So, this research has investigated the effective teaching methodology for teaching English as second language at tertiary level. The research has been based on quantitative paradigm for the collection of data through the tools of close-ended questionnaires and structured observation. And, the data has been analyzed through SPSS software. Moreover, survey and simple random sampling has been used in this research, and teachers of English Department are included in the sample. This research has covered four universities including government and private universities of Karachi though simple random sampling. It has been analyzed that GTM and Direct Method are mostly used by the teachers, and other methods are ignored. And it is concluded that the teachers
\end{abstract}


should use different methods and techniques for teaching according to needs of the learners, so eclectic approach should be used.

\section{KEYWORDS}

Effective, Teaching Methodology, Techniques, ESL and Tertiary level.

\section{INTRODUCTION}

Language is the tool for communication, expressing thoughts and feelings by the usage of words and symbols (Chaudhary, 2012). In today's world, we can't deny the value of English language because it became the primary source of our education (Nadu, 2018). English language plays a vital role, in our personal and professional desires. Learning and teaching has always been the two sides of coin (Sajjad, 2010). However, acquisition of English language has been become a prominent factor for us. To enhance, the communication skills, effective teaching methodology should make the language learning and teaching process innovative and interesting. There shouldn't have any kind of short cuts for improvement of educational techniques (Anil, 2017). However, it is very important to use required and relevant teaching methodology by evaluating student's interest and understanding of learning English as a second language (Ingrarson, 2003). Therefore, language teachers have explored different teaching methods and found just one or more than one method effective and interesting for teaching and learning purposes (Shaikh, 2013).

One of the most traditional methods in all teaching methods is Grammar Translation Method which has also been called "Classical method". It has been used for the purpose of helping learners to deal with the grammar of the foreign language. Learners have been failed to interact and communicate by using GTM method, so Direct Method has been introduced which mainly focus on no translation of foreign language into native language. Same like the Direct Method, Audio Lingual Method has been developed with specific goal (Shaikh, 2013), because during the II world war in United States there was a need for people to learn English language instantly for the purpose of military (Larsen-freeman, 1986).

Although, learners learned second language through ALM, Caleb Gattegno introduced the method of Silent Way, which is related to the cognitive part of the learner, by which learner would be able to use language for self-expression, to express their interests, needs, perceptions and feelings. Moreover, George Lozanov introduced Suggestopedia as it is much faster than Silent Way, because this method has been based on the learner psychological barriers which help learners to accomplish their use of second language on daily basis communication. Teachers should not only consider the feelings of the learner but teacher should develop the understandings among their physical reactions and instincts desires, and it was possible through the method of Community Language 
Learning. All the other methods have focused on the learners speaking skills but Total Physical response have focused on the listening comprehension, which was developed to reduce stress and encourage the learner`s learning. From all the other methods learners know what is grammar and its usage but the Communicative approach was introduced and it has taught the learner how to use the language according to the social context (Larsen-Freeman, 1986).

This research has been based on the effective teaching methodology of teaching English as a second language. All these references have mentioned the importance of teaching methods and have emphasized on new methods, techniques and strategies for teaching English which enhance the interests of the learners towards language learning according to their need.

\section{LITERATURE REVIEW}

In Pakistan, English is the second language of this country and the primary source of education and economy. In educational institutes, English is mandatory subject and is taught as a compulsory subject. According to Dong (2016) English has become a global tool for communication and has become a part of economy. Major aim of teaching English is to provide English language practices and enhance their communicative competence through the usage of effective teaching methods in colleges and universities to make good educational environment.

In the middle of 1970 `s, Asian countries have been worried about the economic change and the position of English in global market. It has only been concluded that the enhancement of English language teaching and learning takes place mainly at tertiary level. The universities must encourage the use of language and improvement of language among students (Wilhelm and Pei, 2008). Foreign countries have been created new teaching methodologies to teach English in the classroom more effectively. Mocinic (2010) has been conducted a research on active strategies in teaching that indicates towards the oral lecture method and emphasize on the use of best teaching method to make students more active and liable in their educational purposes. Moreover, Sajjad (2010), has considered about the perception of best and effective teaching methods on the basis of lecture method because its time consuming, it gives great knowledge and involved students` in listening and taking notes. Sajjad (2010) has pointed out the group discussion method as effective method because of which students participated well and became more creative and enthusiastic in classroom.

Moreover, Lectures remain the effective approach for the classroom teaching. It has been confirmed that lectures are more interesting and develops the involvement of students in classroom (Marmah, 2014). Thomson (2012) has identified the techniques 
and strategies to be used by the teacher to make the students learning effective. $\mathrm{He}$ concluded that teachers should be aware about the techniques and strategies in order to implement in classroom and make the relationship between teacher and student more powerful.

Furthermore, Awan and Shafi (2016) have explored the interest of students and concluded that they prefer Urdu language rather than English language teaching. They usually like to communicate in Urdu instead of English. They have favored GTM rather than Direct Method (DM). Moreover, Khan, Mansoor and Manzoor (2015), have stated that through GTM teaching English is more easy and demandable. Students are satisfied to be taught and learned through this method of teaching language. Through, this point of view of students, researchers have found this method effective. However, Hussain, Inamullah, Naseer-ud-din and Hafizatullah (2009) have mentioned in their research that direct method is more effective teaching methodology rather than GTM. DM has been found more worth able for lower level students as it provides them more opportunities to communicate and interact socially in English language.

Chien (2014) has been conducted a research on the analysis of teaching methods of university students. In which he has been collected the data from teachers and students through observing classes and interviews. It has been concluded that teaching English in classroom is not related to one method, and the methods should be used according to the needs and interests of the learners. Moreover, Taralunga (2006) has conducted the research on the concepts of teaching methodology in English language concerning teaching methods and concluded that learning and teaching English through different approaches is more valuable, Students` learning must take place according to the requirements in classroom. According to Anil (2017) applying innovative teaching methods in language classroom through creative teaching techniques is important. To enhance the level of students learning, teachers must focus on different activities for students' development of language learning skills. Teacher should create a comfortable environment in which students feel easy to become a part of any learning process. Teacher should encourage students and give space to every student to think critically and creatively, through using innovative methodologies, strategies and techniques in teaching English in the classroom. Teacher should use the effective teaching methods in learning classroom because students can easily participate in classroom with full of confidence.

Language teachers have been experimented certain types of language teaching methods in combination and isolation and have found one or more than one methodology as an effective teaching method which is worth using (Shaikh, 2013). It is very difficult to say that which method is more effective and more valuable than others. Usage of methods should be based on classroom needs, requirements, 
intellectual of individual, learning experience, cultural background of students and attitudes towards teaching English as a second language (Shaikh, 2013).

Most of the researches have been conducted intentionally on techniques of teaching English language, strategies, analysis of students' perceptions, importance of grammar translation method GTM and DM and many more methods like cooperative approach (CL), communicative language teaching (CLT), lecture approach, group discussion approach etc. and to find out the effective teaching methodology for teaching English, at tertiary level in Karachi.

\section{RESEARCH OBJECTIVE}

1. To explore out the effective teaching methodology for teaching English as second language (ESL) at tertiary level.

\section{RESEARCH QUESTION}

1. What is the effective teaching methodology for teaching English as second language (ESL) at tertiary level?

\section{RESEARCH METHODOLOGY}

Survey has been used for collecting data, and quantitative paradigm has been used. Data collection has been done through the tools of questionnaires consist of 20 statements given to the teachers of universities and classes have been observed through checklist observation. Moreover, the population includes the teachers of different universities of Karachi as this research has included the English language teachers from different Universities. Four Universities have been randomly selected through simple random sampling. And, here Government and Private Universities of Karachi have been included for the data collection. Simple random sampling has been used for this research, have been used for data collection. The sample of this research includes 27 teachers from all four Universities of Karachi, who have answered the Questionnaire and 4 teachers have been selected for classroom Observation, and two classes of every teacher have been observed.

\section{Data analysis}

\section{Questionnaire Analysis}

A well-organized questionnaire has been given to the teachers of English of Tertiary level. Questionnaires consist of 20 statements and have been distributed personally. Questionnaire has been validated by three experts and changes have been incorporated according to the suggestion. Also, permission has been taken from the HOD of all four universities and they have been informed that the identity will be kept confidentially. And, the data has been analyzed through SPSS software. 


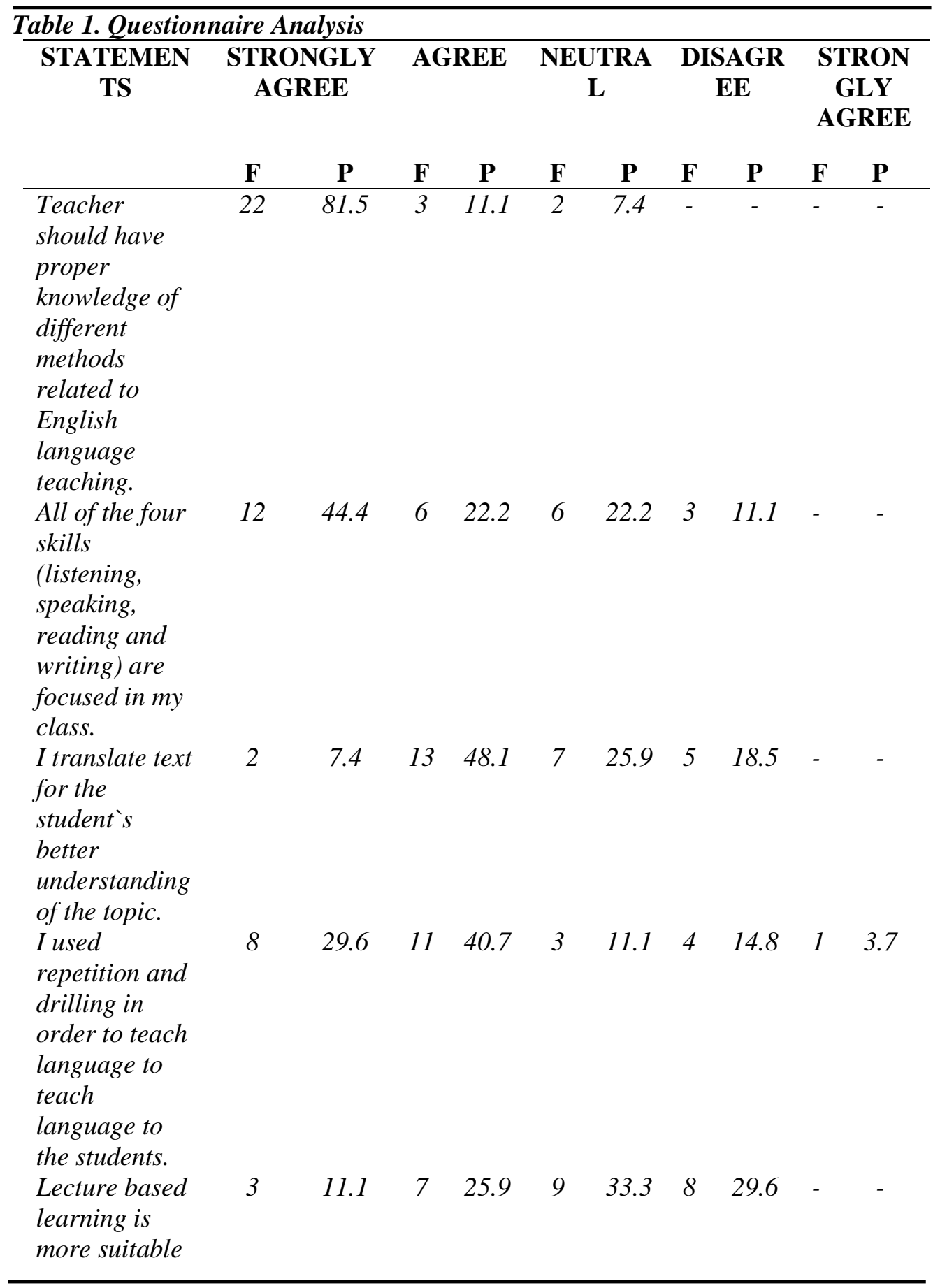




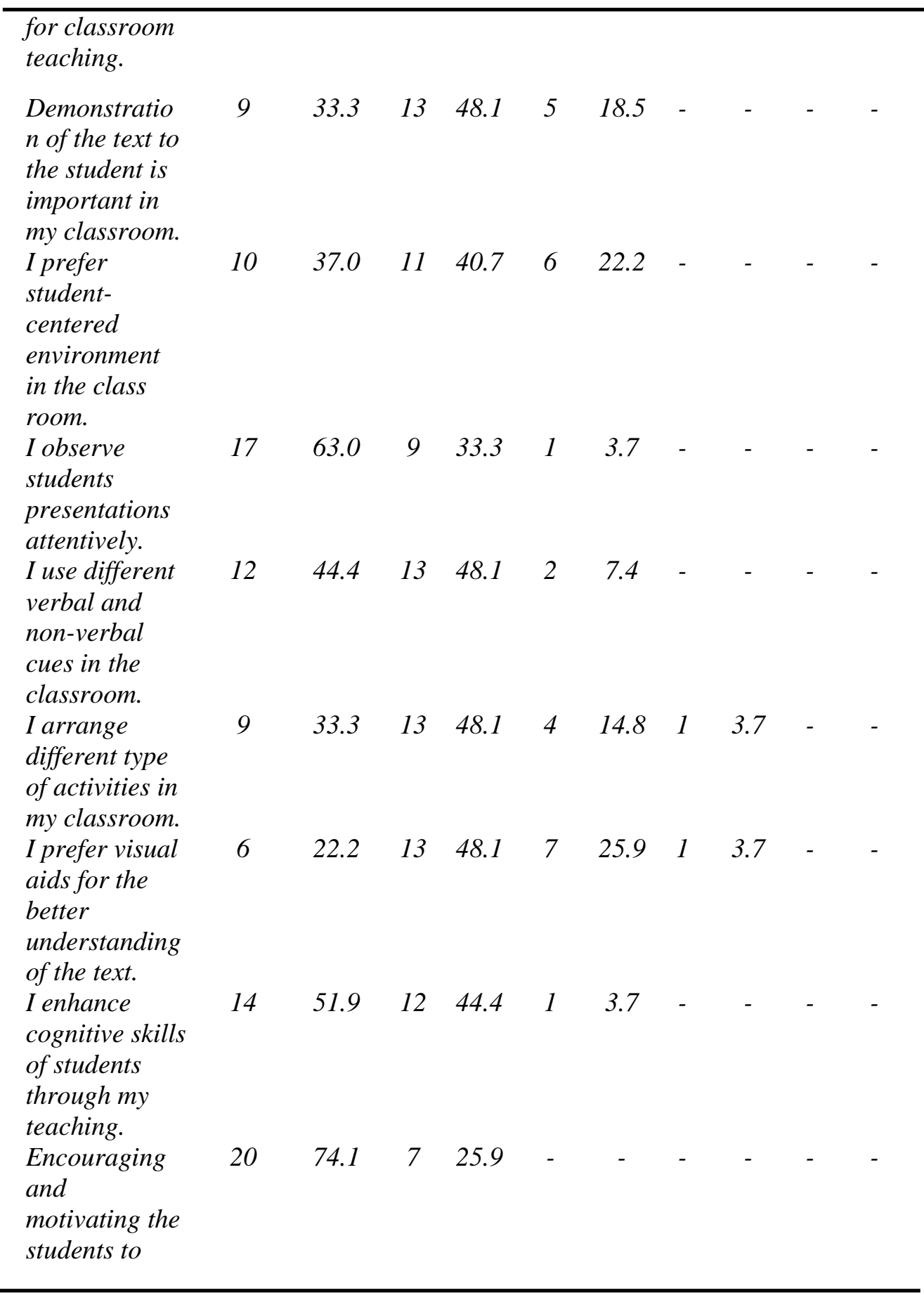




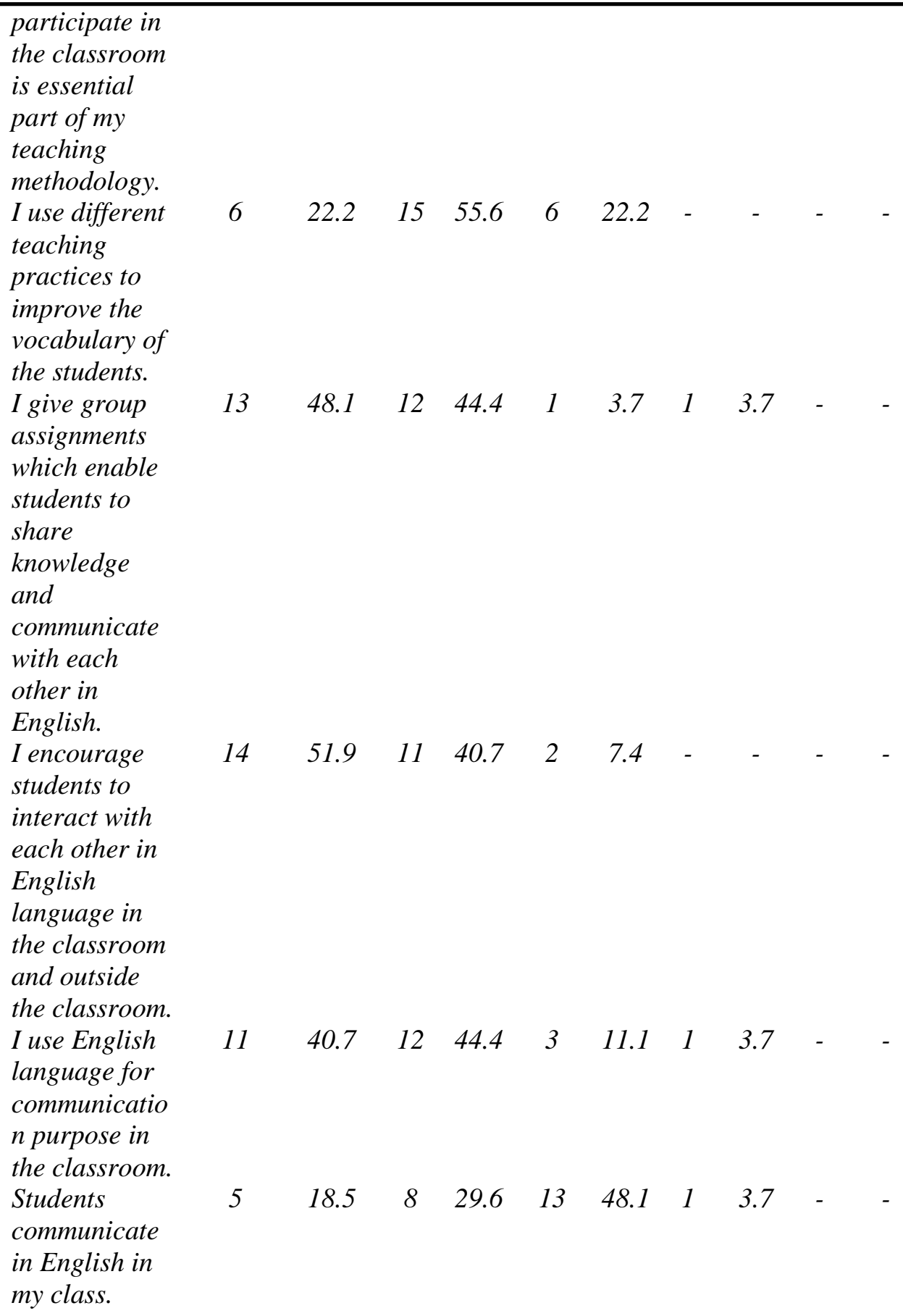

$\begin{array}{lllllllllll}5 & -18.5 & 8 & 29.6 & 13 & 48.1 & 1 & 3.7 & -\end{array}$


PJER, Vol 4, Issue 4 (2021)

Effective teaching methodology ...

\begin{tabular}{|c|c|c|c|c|c|c|c|c|c|c|}
\hline $\begin{array}{l}\text { I provide } \\
\text { comfortable } \\
\text { learning } \\
\text { environment } \\
\text { to my students. } \\
\text { A teacher } \\
\text { should inspire } \\
\text { the students to } \\
\text { learn. }\end{array}$ & 23 & 48.1 & 11 & 40.7 & 3 & 11.1 & - & - & - & - \\
\hline
\end{tabular}

Responding to the first statement that they have proper knowledge of different method of teaching English, 92.6\% participants agreed.

Responding to the second statement that their teaching focuses on all four skills, $66.6 \%$ participants agreed.

In response to the third statement that they translate text for the understanding of students, $55.5 \% \%$ participants agreed.

In response to the fourth statement that they used repetition and drilling in order to teach language, $70.3 \%$ participants agreed.

Responding to the fifth statement that they prefer lecture based learning in which, $37.0 \%$ participants agreed.

Moreover, in response to sixth statement that they use demonstration of text, $81.4 \%$ participants agreed.

Furthermore, responding to the seventh statement that they prefer student-centered environment, $77.7 \%$ participants agreed.

In response to the eight statement that they observed student's presentations attentively, $96.3 \%$ participants agreed.

Likewise, responding to the ninth statement that they used verbal and non-verbal for communication, $92.5 \%$ participants agreed.

Responding to the tenth statement that they use different types of activities in classroom, $81.4 \%$ participants agreed.

In response to the eleventh statement that they use visual aids in classroom, 70.3\% participants agreed.

In addition, in response to the twelfth statement that they enhance cognitive thinking in students, $96.3 \%$ participants agreed.

Furthermore, responding to the thirteenth statement that they encourage and motivate students to participate, $74.1 \%$ participants agreed.

In response to the fourteenth statement that they used different teaching practice to improve the vocabulary of students, $77.8 \%$ participants agreed.

Moreover, responding to the fifteenth statement that they give group assignment to students, $92.5 \%$ participants agreed. 
Furthermore, responding to the sixteenth statement that they encourage students to in English language, $92.6 \%$ participants agreed.

Responding to the seventeenth statement that they use English language for communication purpose, $85.1 \%$ participants agreed.

In response to the eighteenth statement that students communicate in English in their classroom, $48.1 \%$ participants agreed.

Responding to the nineteenth statement that they provide comfortable learning environment, $88.8 \%$ participants strongly agreed.

Lastly, in response to the twentieth statement that teacher should inspire the student to learn language, $85.2 \%$ participants have been strongly agreed.

\section{Observation Analysis}

The second tool for collecting data is classroom observation. Two classes of four teachers have been observed through well-organized observation checklist.

Table 2: Observation Analysis

\begin{tabular}{|c|c|c|c|c|c|}
\hline & \multirow{2}{*}{ STATEMENTS } & \multicolumn{2}{|c|}{ YES } & \multicolumn{2}{|c|}{ NO } \\
\hline & & $F$ & $P$ & $F$ & $P$ \\
\hline 1. & $\begin{array}{l}\text { Class is student- } \\
\text { centered. }\end{array}$ & 5 & $62.5 \%$ & 3 & $37.5 \%$ \\
\hline 2. & $\begin{array}{l}\text { Class is teacher- } \\
\text { centered. }\end{array}$ & 3 & $37.5 \%$ & 5 & $62.5 \%$ \\
\hline 3. & $\begin{array}{lr}\text { Teacher uses } & \text { English } \\
\text { language } & \text { to }\end{array}$ & 5 & $62.5 \%$ & 3 & $37.5 \%$ \\
\hline & $\begin{array}{l}\text { communicate in the } \\
\text { classroom. }\end{array}$ & & & & \\
\hline 4. & $\begin{array}{lr}\text { Student uses } & \text { English } \\
\text { language } & \text { to }\end{array}$ & 5 & $62.5 \%$ & 3 & $37.5 \%$ \\
\hline & $\begin{array}{l}\text { communicate in the } \\
\text { classroom. }\end{array}$ & & & & \\
\hline 5. & $\begin{array}{l}\text { Teacher uses repetition } \\
\text { and drilling to teach } \\
\text { language to the students. }\end{array}$ & 2 & 25.0 & 6 & 75.0 \\
\hline 6. & $\begin{array}{l}\text { Teacher motivates the } \\
\text { students. }\end{array}$ & 7 & 87.5 & 1 & 12.5 \\
\hline 7. & $\begin{array}{l}\text { Teacher gives } \\
\text { demonstration of a text } \\
\text { or a passage. }\end{array}$ & 6 & 75.0 & 2 & 25.0 \\
\hline 8. & $\begin{array}{l}\text { Teacher makes learning } \\
\text { easy. }\end{array}$ & 8 & 100 & - & - \\
\hline
\end{tabular}




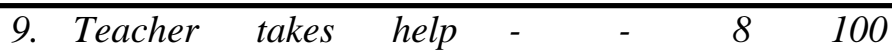
through visual aids.

10. Teacher enhances the $5 \quad 62.5 \% \quad 3 \quad 37.5$ cognitive skills of the students.

$\begin{array}{llllll}\text { 11. Students actively } & 6 & 75.0 & 2 & 25.0\end{array}$ participate in the classroom.

12. Students ask questions. $\quad \begin{array}{lllll}7 & 87.5 & 1 & 12.5\end{array}$

13. Listening, speaking, $\begin{array}{lllll}3 & 37.5 & 5 & 62.5\end{array}$ reading and writing are focused.

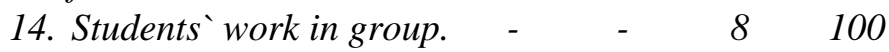

15. Teacher enhances $\begin{array}{lllll}2 & 25.0 & 6 & 75.0\end{array}$ learning in students through playing different games.

16. Grammar is focused. $\quad 8 \quad 100 \quad-\quad-$

17. Teacher uses verbal and $8 \quad 100 \quad-\quad$ non-verbal channels for feedback in the classroom.

18. Teacher corrects $\begin{array}{lllll}4 & 50.0 & 4 & 50.0\end{array}$ students on the spot.

19. Teacher structures the $1 \quad 12.5 \quad 7 \quad 87,5$ classroom arrangements.

20. Teacher encourages the $8100 \quad-\quad$ students to communicate in English language.

Firstly, it has been observed that $62.5 \%$ classes are student-centered whereas, $37.5 \%$ classes are not student-centered.

Secondly, it has also been observed that $37.5 \%$ classes are teacher-centered while, $62.5 \%$ classes are not teacher-centered.

Thirdly, it has been observed that $62.5 \%$ teachers use English language to communicate in English whereas, 37.5\% teachers don't use English language to communicate.

Furthermore, it is also observed that $62.5 \%$ students use English language to 
communicate in English whereas, 37.5\% students don`t use English language to communicate.

It has also been observed that $25.0 \%$ teachers use repetition and drilling while $75.0 \%$ teachers don`t used repetition and drilling for teaching English language.

Moreover, it has also been observed that $87.5 \%$ teachers motivate students whereas $12.5 \%$ teachers don't motivates the students in classroom.

It is also observed that $75.0 \%$ teachers give demonstration while $25.0 \%$ teachers don ${ }^{`} t$ give demonstration of the text in classroom.

Furthermore, it has been observed that $100 \%$ teachers make learning easy for the students.

It has been observed that $100 \%$ teachers don't used visual aids for help in learning. Moreover, $62.5 \%$ teachers enhance the cognitive skills whereas $37.5 \%$ teachers don't enhance the cognitive skills of the students.

It has been observed that $75.0 \%$ students actively participate while $25.0 \%$ students don't actively participate in the classroom.

Similarly, it has also been observed that $87.5 \%$ students ask questions whereas $12.5 \%$ students don`t ask questions.

Also, it has been observed that $37.5 \%$ skills are focused whereas $62.5 \%$ skills are not focused in the classroom.

Further, it has been observed that $100 \%$ student don 't work in group in the classroom. It has also been observed that $25.0 \%$ teachers enhance the learning in students through different games whereas, $75.0 \%$ teachers don't enhance the learning in students through games.

Furthermore, it has been observed that $100 \%$ grammar is focused in the classroom.

Whereas, it has also been observed that $100 \%$ verbal and non-verbal channels are used by teachers in the classroom.

Moreover, it has also been observed that $50.0 \%$ teachers' correct students on the spot while $50.0 \%$ teachers don't correct students on the spot.

It has been observed that $12.5 \%$ teachers structure the classroom while $87.5 \%$ teachers don't structures the classroom.

And, it has been observed that $100 \%$ teacher encourage students to communicate in English language.

\section{DISCUSSION}

The result of this research has shown that the teachers are using very few methods, and the focus is on Direct Method and GTM. But the teachers should cover different methods in their teaching to make learning interesting for their students. This research has concluded that Eclectic approach should be used for teaching a language in which the teacher teaches students with different methods and techniques for the development of students learning abilities according to their needs. As, Tare (2016) has stated that teaching and learning requires creativity and innovation in learning strategies and 
techniques and there are lots of different methods that can be applied in the classroom for better learning of the students.

This research has been conducted in four different universities of Karachi including all government and private sectors through simple random sampling. Data has been collected through the questionnaires and observations. Questionnaire consisting of 20 statements have been given to the teachers of different universities. Whereas, observation has been done through check list of four different teachers, classes. And, both the data has been analyzed through SPSS software. It has been analyzed through the result of questionnaires that teachers should have proper knowledge of all methods and must have command on all four skills. Moreover, Tare (2016) has stated in his research that in order to deal with the students, teachers should make learning innovative and effective. It has also been found out that teachers used translation, demonstration, repetition and prefer lecture based learning to make teaching easy for the learners. Same as, Ramsden (2003) has been stated that students are passive learners; and knowledge is transmitted by the lecture. Whereas, Vedanayagam (1994) has stated that the lecture based learning is a one-way process, there isn't any much interaction between students and teachers developed. Further, it has been analyzed that teachers enhance cognitive skills in students through their teaching. Furthermore, it has also been investigated that teachers encourage students for their learning and provide comfortable learning environment.

Whereas, while observing the classes of the teachers, it has been found out that classes are student-centered instead of teacher-centered. Rowland (1996) has been suggested that to facilitate students learning it is essential for teachers to be well aware about the student's understandings and intentions towards learning. It is also observed that teachers have great communication strategies but they have not covered the demands of all four skills. Furthermore, teachers have not used visual aids for innovation in learning. Whereas, it is also observed that teacher give importance to the cognitive development of students. The result has shown that grammar is highly focused, grammar translations method and direct method has been observed in classroom, and the other material are not focused. Whereas, learning a foreign language is a very complex process and for this grammar is not just compulsory but there is a need to develop the interest of the students through cognitive learning, Graff (1985).

\section{RECOMMENDATION}

This research has been focused on the teaching methods at tertiary level. Similarly, researchers can investigate the teaching methods used at the primary and secondary level and comparative study of all the teaching methods can also be concluded. 


\section{REFERENCES}

Awan, G. A, Shafi, M. (2016). Analysis of Teaching Methods of English Language at government school of D.G. Khan City-Pakistan. An international peer-reviewed Journal, 26. 9-17. Retrieved, March 25, 2019 https://mail.google.com/mail/u/1/\#inbox/FMfcgxwBVWKcxkjQdRGmlhXzVkpbxS $\underline{\mathrm{vc}}$ ?projector $=1 \&$ messagePartId $=0.5$

Anil, B. (2017). Applying innovative teaching methods in a second language classroom. International journal of research in English education, 1. (1), 1-9. Retrieved, February 2, 2019. Retrieved: http://ijreeonline.com/article-1-55-en.pdf

Chien, C. (2014). Analysis of EFL teaching Methods for Taiwan University Students. Journal of Language Teaching and Research, 5. (5), 985-993. Retrieved, April 2, 2019 http://citeseerx.ist.psu.edu/viewdoc/download?doi=10.1.1.831.6853\&rep=rep1\&type $=$ pdf

Dong, X. (2016). Research on the teaching methods of college English, Scientific research publishing, 7. 1233-1236. Retrieved, February 2, 2019 https://www.scirp.org/pdf/CE_2016062116122386.pdf

Hussain, I. Inamullah, H. Naseer-ud-din, M. Hafizatullah, H. (2009), Role of the Direct Teaching Method in the Academic Achievement of students in English at the Secondary level. Journal of College Teaching and Learning, 6. (4), 69-72. Retrieved, March 24, 2019

https://www.researchgate.net/publication/298796675_Role_Of_The Direct Teachin g_Method_In_The_Academic_Achievement_Of_Students_In_English_At_The_Sec ondary Level

Khan, A. B, Mansoor, H. S, Manzoor, S. (2015). The Effectiveness of Grammar Translation Method in Teaching and learning of language at Intermediate level. International Journal of Multidisciplinary Research and Modern Education, 1. (1), 629-633. Retrieved, March 25, 2019 https://www.researchgate.net/publication/328578620_The_Effectiveness_of_Gramm ar_Translation_Method_in_Teaching_and_Learning_of_English_Language_at_Inter mediate Level

Marmah, A. A. (2014). Students Perception about the lecture as the method of Teaching in Tertiary institutions. Views of students from college of technology education, Kumsai (coltek). International Journal of Education and Research, 2. (6), 601-612. Retrieved, April 2, 2019 https://ijern.com/journal/June-2014/50.pdf

Mocinic, S. N. (2012). Active teaching strategies in higher education, Preliminary announcement, 7 (2), 97-105. Retrieved. April 2, 2019 https://www.researchgate.net/publication/236679382_Active_teaching_strategies_in _higher_education

Sajjad, S. (2010). Effective teaching methods at higher education level, Pakistan journal of special education, 11, 29-43. Retrieved. February 2, 2019 http://class.web.nthu.edu.tw/ezfiles/669/1669/img/1381/1.Effectiveteachingmethods athighereducationlevel.pdf

Shaikh, S. F. (2013). Effective methods of teaching English as a second language in the 
classroom, International journal of sciences and research (IJSR), 4 (2), 979-984.

Retrieved. February 2, 2019

https://www.ijsr.net/archive/v4i2/SUB151296.pdf

Thomson, N. (2012). Language teaching strategies and techniques used to support students learning in a language other than their mother tongue. Executive summary. Retrieved. February 2, 2019

https://www.ibo.org/contentassets/4ccc99665bc04f3686957ee197c13855/thompson execsum_8-29-12.pdf

Taralunga, E. (2006). Concepts on the methodology of teaching English, the economic journal of Takasaki City University of economics, 48 (3), 169-188. Retrieved. February 22019 http://www.b-li.ir/ar/01Methods/tamura.pdf

Withelm, K. H, Pei, B.C. (2008). University Teachers and Students` Perceptions of ELT Methodologies and their Effectiveness. GEMA Online Journal of Language and studies, 8 (2), 79- 102. Retrieved, February 2, 2019 http://journalarticle.ukm.my/2274/1/page1_21.pdf

Mart, C. (2013). The Direct Method: A Good Start to Teach Oral Language. International Journal of Academic Research in Business and Social Sciences, 3 (11), 182-1184. Retrieved, November 2, 2019 https://www.researchgate.net/publication/271146717_The DirectMethod_A_Good_Start_to_Teach_Oral_Language

Chung, G. (2014). A Study of Instructional Psychology on Grammar Translation Method from Chinese I-Ching. Journal of Studies in Social Sciences, 9 (11), 22-23. Retrieved, November 11, 2019 file:///C:/Users/welcome/Downloads/867-2003-1-PB.pdf

Tare, N. (2016). Effective Methods of Teaching and Learning English as the Second Language (E2L). Epitome: International journal of Multidisciplinary Research, 2 (12), 45-49. Retrieved, March 25, 2019

Graff, W. (1985). Language and Learning Principles. Longmans Green and Co LTD. London, UK. (pp. 60-67)

Ramsden, P. (2003). Learning to Teach in Higher education. ( $2^{\text {nd }}$ ed.), London, Routledge Falmer.

Valanayagem, E.G. (1994). Teaching Technology for College Teachers. New Delhi. Sterling Publishers.

Effective. 2015 ( $9^{\text {th }}$ edition). Oxford Advanced Learner Dictionary: Oxford University Press.

Teaching Methodology. 2015 ( $9^{\text {th }}$ edition). Oxford Advanced Learner Dictionary: Oxford University Press.

ESL. 2015 ( $9^{\text {th }}$ edition). Oxford Advanced Learner Dictionary: Oxford University Press. English.2015 ( $9^{\text {th }}$ edition). Oxford Advanced Learner Dictionary: Oxford University Press. Techniques.2015 ( $9^{\text {th }}$ edition). Oxford Advanced Learner Dictionary: Oxford University Press. https://www.academia.edu/25428308/Techniques_and_Principles_in_Language_Tea ching_2nd_Edition_-_Diane_Larsen_and_Freeman

Ramos, A. (2015). Methods and Teachings Strategies Used by Teachers Education Faculty Members in one State University in the Philippines. Asia Pacific Journal of Multidisciplinary Research, 3 (5), 36-44. Retrieved, March 16, 19 
https://pdfs.semanticscholar.org/7a51/ceffcae5bd74fa870ae65a73fa1121348d92.pdf

Zhao, K. Ting, K. (2013). Students Attitudes Towards Teaching Methods Used in Universities the UK. Review of European Studies, 5 (4), 71-81. Retrieved, March 11, 2019 file://C:/Users/welcome/Downloads/27183-97723-1-PB\%20(1).pdf

Tamura, E. (2006). Concepts on the Methodology of Teaching English. The Economic Journal of Takasaki City University of Economics, 48 (3), 169-188. Retrieved, April 6, 2019 http://www.b-li.ir/ar/01Methods/tamura.pdf

Schwartz, B.D. (2003). Child L2 acquisition: paving the way. In B. Beachley, A. Brown \& F. Collin (eds.), proceeding of the $27^{\text {th }}$ annual Boston Universities Conference on language development. Somerville, MA: Cascadilla Press, pp-26-20. Scrivener, J. (2007).

Learning teaching ( $2^{\text {nd }}$ edn). London: Macmillan. Retrieved, June 4, 2019. https://www.semanticscholar.org/paper/Running-Head-\%3A-Older-Age-in-Child-L2-A-Can-Be-\%3A-of-RothmanLong/abc48661c46028c97b6bbe042c01ed698bed3d9d

Unsworth, S. (2005). Child L2, adult L2, Child L1: Differences and similarities. A study on the acquisition of direct object scrambling in Dutch. Ph.D. Dissertation, Utrecht University. Retrieved, July 5, 2019 https://www.lotpublications.nl/Documents/119_fulltext.pdf

Pollock, J.E. (2007). Improve student learning one teacher at a time. Acquisition for supervision and curriculum development. Alexandria, VA. https://epdf.pub/improving-student-learning-one-teacher-at-a-time.html https://shodhganga.inflibnet.ac.in/bitstream/10603/16244/8/08_chapter\%202.pdf

Gilkerson, J. (2006). Acquiring English practices verbs: Age and transfer effect in second language acquisition. Ph.D. Dissertation, University of California at Los Angeles. https://linguistics.ucla.edu/people/diss/gilkerson_diss.pdf

Ingvarson, L. (2003). Getting professional developmental right. Proceeding of 2003 ACER Research conference. Melbourne: ACER. 